\title{
Serological investigation of brucellosis and its asso- ciation with abortion in sheep and goats in selected districts of Jimma zone, southwestern Ethiopia
}

\author{
Dereje Tulu ${ }^{1^{*}}$, Abiy Gojam ${ }^{2}$ and Benti Deresa ${ }^{3}$ \\ ${ }^{1}$ Ethiopian Institute of Agricultural Research, Tepi Agricultural Research Center, P.O. Box 34, \\ Tepi, Ethiopia \\ ${ }^{2}$ Jimma Zone Livestock and Fish Resource Office, P.O. Box 166, Jimma, Ethiopia \\ ${ }^{3}$ School of Veterinary Medicine, College of Agriculture and Veterinary Medicine, Jimma Univer- \\ sity, P.O. Box 307, Jimma, Ethiopia \\ ${ }^{*}$ Corresponding author.Tel.: +251920654572; E-mail address: derejetulu5@gmail.com
}

\begin{abstract}
The occurrence of brucellosis in different species of livestock has been reported from different parts of Ethiopia, however, the serostatus and risk factors of this disease in small ruminants is not well documented in southwestern parts of the country. This study was conducted from October 2016 to October 2017 to investigate the seroprevalence and associated risk factors of brucellosis as well as its association with abortion in sheep and goats in selected districts of Jimma zone. A total of 804 small ruminants (402 sheep and 402 goats) were randomly selected and blood samples were collected for serological tests. The presence of antibody to Brucella was screened by Rose Bengal Plate Test and confirmed using the complement fixation test. Seroprevalence of $4.2 \%$ in sheep and $5.2 \%$ in goats was recorded in this study. An overall seroprevalence of $4.7 \%$ was recorded in small ruminants in the study areas. Brucella seropositivity was observed more frequently among sheep and goats with a history of abortion (6.7\%) than animals that have no history of abortion (3.7\%), however, the difference noted was not statistically significant. Older age (OR 3.9, CI = 1.43-9.94), pregnancy (OR 2.6, CI $=1.19-5.72)$, late term gestation $(\mathrm{OR} 2.4$, CI $=1.54-3.78)$, mixed flock (OR 2.8, CI = 1.33-5.89) and larger flock size (OR 2.7, $\mathrm{CI}=1.08-6.95)$ were noted to have more number of reactors. Hence, it is important to consider brucellosis as one of the diseases that needs attention and further study should be conducted to identify the circulating Brucella species and other causes of abortion in sheep and goats. Besides, this finding warrants the need for further investigation on its public health impact in the region.
\end{abstract}

Keywords: Brucellosis; Epidemiology; Sheep; Goat; Jimma Zone 


\section{Introduction}

Ethiopia has a huge number of small ruminants with an estimated population of 30.7 million sheep and 30.2 million goats (CSA, 2017). However, the disease of reproduction is challenging to the rearing of sheep and goats in the country (ESGPIP, 2011). Infectious reproductive diseases of sheep and goats are part of the major flock health problems known to constrain the sector. These diseases usually manifest themselves through infertility, abortion, stillbirth and weak offspring (Radostits et al., 2007). Several infectious agents including, bacteria, viruses and protozoa are accountable for abortion in sheep and goats. Abortion is also caused by non-infectious factors such as toxic substances, metabolic, nutritional and physical injuries. These causes also have a significant impact on the overall productivity of sheep and goats (Daniel and Marley, 2008; Mirkena et al., 2011). Among infectious causes of abortion, Brucella is one of the known bacterial pathogens causing tremendous economic losses (FAO, 2003; Tegegn et al., 2016).

Brucella melitensis and B. ovis are the two important Brucella species known to affect sheep and goats, however; B. abortus is also been incremented occasionally in sheep and goats (Radostits et al., 2007; Akhvledian et al., 2010). The disease is manifested by late-term abortions, weak lambs and kids, stillbirths, infertility and characterized mainly by the retained fetal membrane (Radostits et al., 2007). Brucella infection in sheep and goats is a well-known disease worldwide. However, the disease is a serious problem in developing countries (FAO, 2003; Njeru et al., 2016; Shirima and Kunda, 2016). The prevalence of brucellosis is affected by several risk factors such as production system, host and environmental factors (Radostits et al., 2007). In sexually mature sheep and goats, brucellosis restricts to the reproductive tract and typically causes placentitis and abortion in pregnant ones. Brucella melitensis and B. abortus are zoonotic pathogens that cause disease in humans (Pappas et al., 2006; Radostits et al., 2007).

Many developing countries with a limited resource like Ethiopia are facing other priority diseases and have not yet performed an aspect of brucellosis intervention. The epidemiology, and control and prevention methods of brucellosis in sheep and goats were not well understood (McDermont and Arimi, 2002). As a result, brucellosis remains challenging in sheep and goat population and cause huge economic and public health problems in the country (Tegegn et al., 2016; Mohammed et al., 2017). Brucellosis also causes reduce the foreign cur- 
rency earnings through rejection of export sheep and goats from international markets (LMA, 2005).

Ethiopia has various agro-ecological zones that have contributed to the development of different livestock production systems (Beruktayet and Mersha, 2016). Production system, breed, and environmental factors greatly influence the spread of brucellosis among the causes of abortion (Tulu et al., 2018). Several sheep and goats breed in Ethiopia are reared in different agro-ecological zones and production systems. The extensive production system of the country is responsible for the mixing of different livestock species for maintenance and transmission of brucellosis (Megersa et al., 2011b). Close animal-human contact and traditional raw animal product consumption make zoonosis among the main public health hazards in Ethiopia. Hence, detailed epidemiological studies for the implementation of applicable control strategies were needed (Addis and Desalegn, 2018). Several studies were done on sheep and goat brucellosis in different parts of the country (Teshale et al., 2006; Asmare et al., 2010; Megersa et al., 2011b; Dabassa et al., 2013; Sintayehu et al., 2015). Nevertheless, reports from south western part of the country are very limited. Therefore, this study aimed to estimate the seroprevalence and identify the associated risk factors of brucellosis. Besides it attempts to observe the association of Brucella reactors with abortion in sheep and goats in selected districts of the study area.

\section{Materials and Methods}

\section{Description of study areas}

The study was carried out in Limu Seka and Chora Boter districts of the Jimma zone. Limu Seka district located about $463 \mathrm{~km}$ from Addis Ababa, the capital city of Ethiopia; and $109 \mathrm{~km}$ from Jimma town, the capital city of Jimma zone. The district covers an area of approximately $1,694 \mathrm{~km}^{2}$ and is divided into 38 kebeles (the smallest administrative units). The agro-ecology of the district is characterized by highland (13\%), mid-highland (55\%) and lowland (32\%). The altitude of the district is between 1,400-2,200 meters above sea level. Chora Boter district is located $466 \mathrm{~km}$ away from Addis Ababa, and $112 \mathrm{~km}$ from Jimma town, zonal capital. This district has 19 kebeles; and agro-ecologically it is characterized by highland, mid-highland, and lowland. The altitude of the district is between 1,100-2,200 meters above sea level and has an average temperature of $22^{\circ} \mathrm{C}$. Chora Boter district has 228,846 head of cattle, 47,854 head of sheep, and 68,037 head of goats. Both districts have two distinct seasons. 
The rainy season is starting in late March and ending in October, and the dry season is occurring from November to early March.

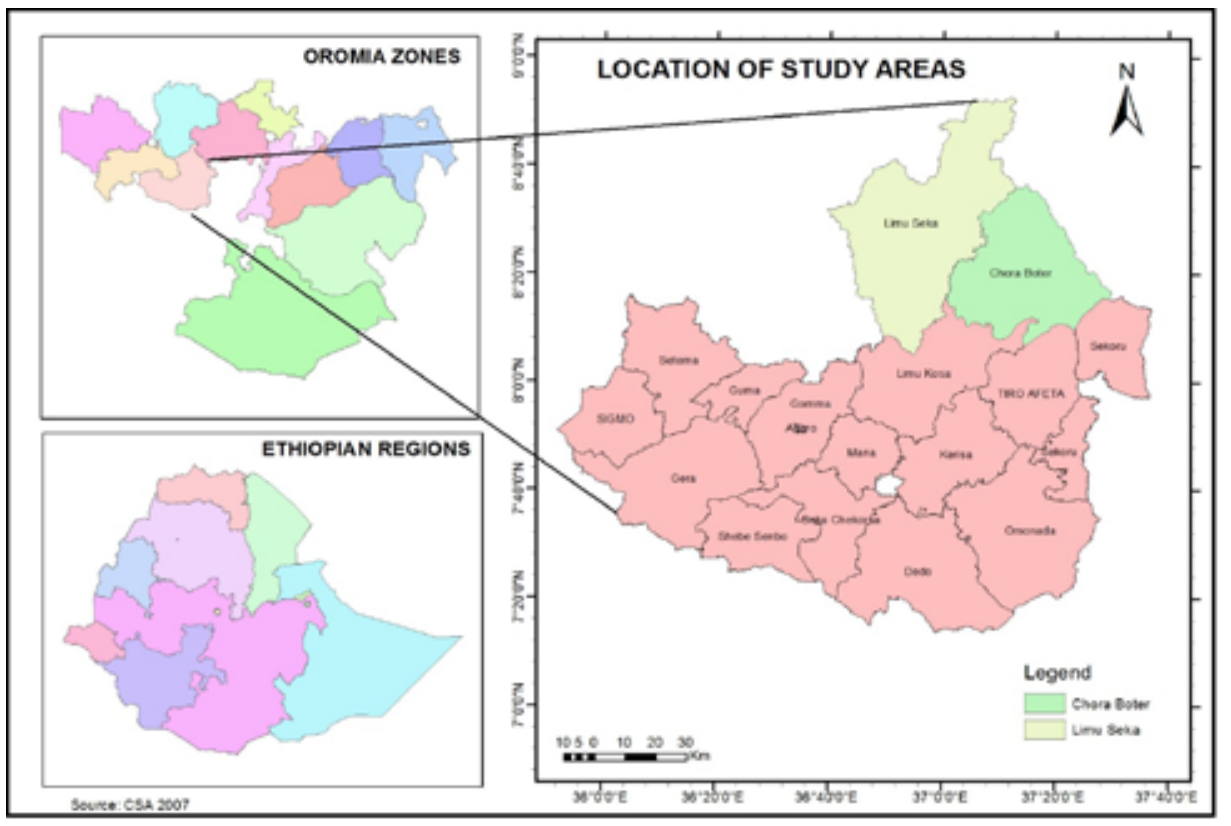

Figure 1: Map of the study areas

\section{Study design and animals}

A cross-sectional study was carried out from October 2016 to October 2017 in selected districts of Jimma zone to investigate the seroprevalence and associated risk factors of brucellosis as well as its association with abortion in sheep and goats. The target population of this study comprises female sheep and goats in study districts, namely Limu Seka and Chora Boter. Sheep and goats older than three months (to exclude maternal immunity) were randomly selected and included in the study. Age was determined using dentition and categorized as $<1$ year, 1 year to 2 years and $>2$ years (ESGPIP, 2009). The number of sheep and goats farmers own was categorized as small $(<7$ sheep/ goats), medium (8-12 sheep/goats) and large (>12 sheep/goats) flock sizes. Parity number was categorized as nulliparous (zero parity), monoparous (parity one) and pluriparous ( $\geq$ two parities) (Margatho et al., 2019). Management systems were classified as extensive and semi-intensive based on the criteria adopted by Gizaw et al. (2015). Body condition scoring for sheep and goats 
was conducted using the guidelines established by Langston University (Villaquiran et al., 2007; Kenyon et al., 2014) and ESGPIP (ESGPIP, Technical Bulletin No. 8) guidelines for body condition scoring and for all sheep and goats under the study their body condition grouped into three groups (poor, medium and good). Abortion was defined as loss of fetus or fetuses before 140 days of pregnancy (Margatho et al., 2019). The gestation stage of abortion was categorized as first trimester ( $<50$ days), second trimester (51-100 days) and third trimester (101-154 days) (Bokko, 2011). Properly manage abortion materials when it was buried or burned whereas improperly manage was simply leave it on the ground or give to the dogs. According to the agro-altitudinal and agroclimatology classification of Ethiopia, lowland falls between 500 and 1,500 and midland falls between 1,500 and 2,300 meters above sea level (Libeau et al., 1995).

\section{Sampling techniques and sample size determination}

The multistage sampling method was used to select sampling units from different flocks. Jimma zone and districts (Limu Seka and Chora Boter) were selected purposively based on the dominant of sheep and goats production system, while peasant associations and flocks were selected randomly. The sampling frame of peasant associations were obtained from respective districts agricultural office. A total of ten peasant associations were selected from two districts using a random sampling technique where six peasant associations were from Limu Seka and four of them from Chora Boter based on sheep and goats population. Since there is no previous study on breeding sheep and goat brucellosis in study areas, the sample size was calculated using formula described by Thrusfield (2005) considering an expected prevalence of $50 \%$ and an absolute precision of 5\% with $95 \%$ confidence interval. Substituted each gave 384 animals. Since two populations (sheep and goat) were included in this study, the sample size was double (768). However, a total of 804 small ruminants (402 sheep and 402 goats) were involved to increase the accuracy of the study.

\section{Blood sample collection}

Blood samples collected from the jugular vein, $(3-5 \mathrm{ml})$ aseptically using sterile plain vacutainer tubes and needle, were kept in a slanting position overnight (12 hours) at room temperature to separate the serum. Then sera were gently decanted into sterile screw cupped tubes, labeled and transported in ice packs to Jimma University, College of Agriculture and Veterinary Medicine micro- 
biology laboratory and stored at $-20^{\circ} \mathrm{C}$ until screened and tested for antibodies against natural Brucella microorganisms. As there has never been a history of vaccination for brucellosis, all positive results were attributed to natural infection. Parallel to blood sample collection relevant information such as agro-ecology, management system, flock size, species composition (mixed of sheep and/ goats with cattle), introducing new animals, species, management of aborted material, age (years), parity, body condition, reproduction status, abortion history and frequency, gestation period at abortion and history of retained fetal membrane were collected using separate format.

\section{Serological test}

All serum samples collected were first tested using Rose Bengal Plate Test (RBPT) at the National Veterinary Institute (NVI), Debre Zeit, Ethiopia according to the technique described by Alton (1990). The sera and RBPT reagent were taken from the refrigerator and kept at room temperature for at least 30 minutes before the test was performed. A total of 30 microliters of serum sample was dispensed onto the plate and 30 microliters of RBPT antigen were dropped on the slide with sera. The interpretation of both positive and negative control results was done according to the degree of agglutination and the reaction was read in a good light source or by a magnifying glass when micro agglutination was suspected. The RBPT results were interpreted $0,+,++$ and +++ as has been described by Dohoo et al. (2009), where 0 indicates no agglutination, + indicates barely visible agglutination (using magnifying glasses), ++ indicates fine agglutination and +++ indicates coarse clumping. Those serums identified with no agglutination (0) were regarded as negative, while those with,+++ and +++ were considered as positive. The whole positive serums were confirmed using the complement fixation test (CFT) using standard $B$. abortus S99 (KT153, UK). This test was also done at NVI. The preparation of the reagent was evaluated by titration and performed according to protocols recommended by OIE (2009). Sera with a strong reaction, more than $75 \%$ fixation of complement (3+) at 1:5 dilution or at least with $50 \%$ complement fixation (2+) at 1:10 dilution and above were considered as positive and lack of fixation/complete hemolysis was considered as negative (OIE, 2004).

\section{Data management and analysis}

Data obtained from this study were recorded, coded and stored in Microsoft Excel for Windows 2010 and transferred to STATA version 11.0. Seroprevalence of brucellosis was calculated by dividing the number of seropositive samples 
to the total of sheep and goats samples. Association between brucellosis and presumptive risk factors was analyzed using the logistic regression analysis. The variables with $p$-value less than or equal to 0.25 in univariable logistic regression, after checking for multicollinearity using collinear matrix index and interaction effect using cross-product terms were taken forward for multivariable modeling. The model fitness was observed using the Hosmer-Lemeshow test. The model validate was also evaluated by using the ROC curve. For all statistical analysis, confidence intervals (CI) of $95 \%$ and p-value of 0.05 were used.

\section{Results}

Out of the total 804 sheep and goats sampled, 6.3\% (n=51) of sheep and goats were tested positive on screening using RBPT. Further, confirmation using CFT identified an overall 4.7\% (38/804) prevalence of Brucella antibodies in sheep and goats. Seroprevalence of $4.2 \%$ (17/402) and 5.2\% (21/402) were recorded in sheep and goats, respectively. More seropositivity of Brucella antibody was observed among sheep and goats with the history of abortion (6.7\%) than animals that have no history of abortion (3.7\%). However, there was no difference $(p>0.05)$. Likewise, sheep and goats from a large flock size category were almost three times more likely to be infected with Brucella organisms than small flock size $(\mathrm{OR}=2.8, \mathrm{p}<0.05)$. Similarly, a statistically significant difference in seroprevalence of brucellosis was observed in animals herded with cattle $(p<0.05)$. Mixed (sheep and/goats with cattle) species were almost three times more likely to be infected with Brucella organisms than those having close contact with cattle $(\mathrm{OR}=2.8)$. However, agro-ecology, species, introducing of a new animal, management system and properly manage of aborted material were not able to explain seroprevalence of brucellosis (Table 1). 
Tulu et al.,

Table 1. Univariable logistic regression of environmental-related putative risk factors in study areas

\begin{tabular}{|c|c|c|c|c|c|}
\hline Variables & Categories & $\begin{array}{l}\text { Total } \\
\text { animals } \\
\text { examined }\end{array}$ & $\begin{array}{l}\text { Total } \\
\text { animals } \\
\text { positive }(\%)\end{array}$ & OR (CI; 95\%) & p-value \\
\hline \multirow[t]{2}{*}{ Agro-ecology } & Lowland (Ref.) & 176 & $8(4.55)$ & - & 0.143 \\
\hline & Midland & 628 & $30(4.78)$ & $1.7(0.837-3.430)$ & \\
\hline \multirow[t]{2}{*}{$\begin{array}{l}\text { Management } \\
\text { system }\end{array}$} & $\begin{array}{l}\text { Extensive } \\
\text { (Ref.) }\end{array}$ & 691 & $32(4.63)$ & - & 0.218 \\
\hline & $\begin{array}{l}\text { Semi- } \\
\text { intensive }\end{array}$ & 113 & $6(5.31)$ & $0.6(0.269-1.349)$ & \\
\hline \multirow[t]{3}{*}{ Flock size } & $\begin{array}{l}\text { Small }(<7) \\
\text { (Ref.) }\end{array}$ & 228 & $6(2.63)$ & - & 0.024 \\
\hline & Medium(8-12) & 241 & $7(2.90)$ & $0.9(0.429-1.912)$ & \\
\hline & Large(>12) & 335 & $25(7.46)$ & $2.8(1.154-6.956)$ & \\
\hline \multirow[t]{2}{*}{$\begin{array}{l}\text { Species } \\
\text { composition }\end{array}$} & $\begin{array}{l}\text { Single species } \\
\text { (Ref.) }\end{array}$ & 419 & $11(2.63)$ & - & 0.005 \\
\hline & Mixed & 385 & $27(7.01)$ & $2.8(1.37-5.72)$ & \\
\hline \multirow{2}{*}{$\begin{array}{l}\text { Introducing new } \\
\text { animals }\end{array}$} & No (Ref.) & 457 & $19(4.16)$ & - & 0.893 \\
\hline & Yes & 347 & $19(5.48)$ & $1.1(0.541-2.024)$ & \\
\hline \multirow{2}{*}{$\begin{array}{l}\text { Proper manage } \\
\text { of aborted } \\
\text { material }\end{array}$} & Yes (Ref.) & 247 & $8(3.24)$ & - & 0.190 \\
\hline & No & 527 & $30(5.39)$ & $0.6(0.266-1.302)$ & \\
\hline \multirow[t]{2}{*}{ Species } & Sheep (Ref.) & 402 & $17(4.23)$ & - & 0.507 \\
\hline & Goat & 402 & $21(5.22)$ & $0.8(0.416-1.542)$ & \\
\hline
\end{tabular}

Similarly, Brucella seropositivity was significantly varied among sheep and goat age groups with older age categories are 2.7 times more likely to be $\mathrm{Bru}$ cella seropositive than younger age category $(\mathrm{OR}=2.7, \mathrm{p}<0.05)$. The univariable logistic regression analysis shown that Brucella seroprevalence was a statistically significant difference with gestation stages, with the odd of seropositivity being 1.3 times higher in animal aborted in the third trimester than those have no history of abortion $(\mathrm{OR}=1.3, \mathrm{p}<0.05)$. 
Table 2. Univariable logistic regression of host-related putative risk factors in study areas

\begin{tabular}{|c|c|c|c|c|c|}
\hline Variables & Categories & $\begin{array}{l}\text { Total } \\
\text { animal } \\
\text { examined }\end{array}$ & $\begin{array}{l}\text { Total animal } \\
\text { positive (\%) }\end{array}$ & OR (CI; 95\%) & p-value \\
\hline \multirow[t]{4}{*}{ Age } & & & & & 0.006 \\
\hline & $<1$ year (Ref.) & 236 & $5(2.12)$ & - & \\
\hline & $1-2$ years & 217 & $11(5.07)$ & $1.6(1.42-3.45)$ & \\
\hline & $>2$ years & 351 & $22(6.27)$ & $2.7(1.15-6.66)$ & \\
\hline \multirow[t]{4}{*}{ Parity } & & & & & 0.136 \\
\hline & Nulliparous (Ref.) & 168 & $6(3.57)$ & - & \\
\hline & Monoparous & 207 & $8(3.86)$ & $0.7(0.32-1.77)$ & \\
\hline & Pluriparous & 429 & $24(5.59)$ & $1.6(0.68-3.71)$ & \\
\hline \multirow{4}{*}{$\begin{array}{l}\text { Body } \\
\text { condition }\end{array}$} & & & & & 0.569 \\
\hline & Good (Ref.) & 135 & $4(2.96)$ & - & \\
\hline & Medium & 463 & $24(5.18)$ & $0.6(0.19-1.64)$ & \\
\hline & Poor & 206 & $10(4.85)$ & $0.6(0.18-1.95)$ & \\
\hline \multirow[t]{2}{*}{$\begin{array}{l}\text { Reproduction } \\
\text { status }\end{array}$} & $\begin{array}{l}\text { Non-pregnant } \\
\text { (Ref.) }\end{array}$ & 342 & $11(3.22)$ & - & 0.087 \\
\hline & Pregnant & 462 & $27(5.84)$ & $1.9(0.91-3.82)$ & \\
\hline \multirow[t]{2}{*}{$\begin{array}{l}\text { Abortion } \\
\text { history }\end{array}$} & Absent & 536 & $20(3.7)$ & - & \\
\hline & Present & 268 & $18(6.7)$ & $0.5(0.28-1.03)$ & 0.064 \\
\hline \multirow[t]{4}{*}{$\begin{array}{l}\text { Abortion } \\
\text { frequency }\end{array}$} & & & & & 0.104 \\
\hline & None aborted & 536 & $20(3.7)$ & - & - \\
\hline & Once (Ref.) & 199 & $15(7.5)$ & $0.5(0.24-0.95)$ & \\
\hline & $\geq 2$ & 69 & $3(4.3)$ & $0.9(0.25-2.95)$ & \\
\hline \multirow{5}{*}{$\begin{array}{l}\text { Gestation } \\
\text { period at } \\
\text { abortion }\end{array}$} & & & & & 0.008 \\
\hline & None aborted (Ref.) & 536 & 20 (3.73) & - & \\
\hline & First trimester & 41 & $1(2.43)$ & $0.2(0.09-0.68)$ & \\
\hline & Second trimester & 68 & $4(5.88)$ & $0.3(0.14-0.82)$ & \\
\hline & Third trimester & 159 & $13(8.18)$ & $1.3(1.41-2.60)$ & \\
\hline \multirow{2}{*}{$\begin{array}{l}\text { Retained } \\
\text { placenta }\end{array}$} & Absent (Ref.) & 673 & $29(4.31)$ & - & 0.922 \\
\hline & Present & 131 & $9(6.87)$ & $1.0(0.37-2.48)$ & \\
\hline
\end{tabular}


In multivariable logistic regression analysis, explanatory variables with a $\mathrm{p}$ value of less than or equal to 0.25 in the univariable logistic regression were included. This model showed that older sheep and goats were identified to be Brucella seropositive with the odds of positivity 3.9 (OR=3.9, CI; 1.43-9.94) times more likely than the younger ones. Similarly, this result also shows that sheep and goats that were from a mixed (sheep and/ goat with cattle) species were more likely to be Brucella antibody seropositivity than those having no contact with cattle $(\mathrm{OR}=2.8, \mathrm{CI} ; 1.33-5.89)$. Furthermore, sheep and goats from large flock sizes were also found to be at higher risk of Brucella infection, than those from small flock size (OR=2.7, CI; 1.08-6.95). Likewise, sheep and goat aborting at the third-trimester stage were higher Brucella seropositivity (OR=2.4, CI; 1.54-3.78) than those have no history of abortion. Moreover, reproduction status is statistically significantly different in Brucella antibody seropositivity with pregnant sheep and goats are 2.6 times more likely to harboring Brucella infection than non-pregnant ones (OR=2.6, CI; 1.19-5.72). Hosmer-Lemeshow test (0.5) indicates that the model was fit data well. ROC curve (0.76) indicated the model was good predicting ability. 
Table 3. Final multivariable logistic regression model for brucellosis antibody seropositivity in study areas

\begin{tabular}{|c|c|c|c|c|c|}
\hline Variables & Categories & $\begin{array}{l}\text { Total } \\
\text { animals } \\
\text { examined }\end{array}$ & $\begin{array}{l}\text { Total } \\
\text { animals } \\
\text { positive }\end{array}$ & $\begin{array}{l}\text { Adjusted } \\
\text { OR (CI; } \\
95 \%)\end{array}$ & p-value \\
\hline \multirow[t]{4}{*}{ Age(years) } & & & & & 0.003 \\
\hline & $<1$ year (Ref.) & 236 & $5(2.12)$ & - & - \\
\hline & $1-2$ years & 217 & $11(5.07)$ & $\begin{array}{c}1.6(1.36- \\
3.86)\end{array}$ & 0.040 \\
\hline & $>2$ years & 351 & $22(6.27)$ & $\begin{array}{l}3.9(1.43- \\
9.94)\end{array}$ & 0.007 \\
\hline \multirow[t]{2}{*}{$\begin{array}{l}\text { Species } \\
\text { composition }\end{array}$} & $\begin{array}{l}\text { Single species } \\
\text { (Ref.) }\end{array}$ & 419 & $11(2.63)$ & - & - \\
\hline & Mixed species & 385 & $27(7.01)$ & $2.8(1.33-5.89)$ & 0.007 \\
\hline \multirow[t]{4}{*}{ Flock size } & & & & & 0.017 \\
\hline & Small (<7) (Ref.) & 228 & $6(2.63)$ & - & - \\
\hline & Medium (8-12) & 241 & $7(2.90)$ & $\begin{array}{l}1.8(1.35- \\
2.66)\end{array}$ & 0.039 \\
\hline & Large $(>12)$ & 335 & $25(7.46)$ & $\begin{array}{c}2.7(1.08- \\
6.95)\end{array}$ & 0.034 \\
\hline \multirow[t]{4}{*}{$\begin{array}{l}\text { Gestation } \\
\text { period at } \\
\text { abortion }\end{array}$} & $\begin{array}{l}\text { None aborted } \\
\text { (Ref) }\end{array}$ & 536 & $20(3.73)$ & - & $\begin{array}{l}0.045 \\
-\end{array}$ \\
\hline & First trimester & 41 & $1(2.43)$ & $\begin{array}{l}0.3(0.11- \\
1.03)\end{array}$ & 0.056 \\
\hline & Second trimester & 68 & $4(5.88)$ & $0.5(0.18-1.27)$ & 0.141 \\
\hline & Third trimester & 159 & $13(8.18)$ & $2.4(1.54-3.78)$ & 0.037 \\
\hline \multirow[t]{2}{*}{$\begin{array}{l}\text { Reproduction } \\
\text { status }\end{array}$} & $\begin{array}{l}\text { Non-pregnant } \\
\text { (Ref.) }\end{array}$ & 342 & $11(3.22)$ & - & - \\
\hline & Pregnant & 462 & $27(5.84)$ & $2.6(1.19-5.72)$ & 0.017 \\
\hline
\end{tabular}

\section{Discussion}

In the present study, an overall $4.7 \%$ seroprevalence of brucellosis was recorded in female sheep and goats in study areas. The seroprevalence detected in this study is in line with the findings of Mengistu (2007), Wesinew et al. (2013) and Deddefo et al. (2015), who reported seroprevalence of 5.1\%, 4.8\%, and $4.6 \%$, respectively. However, this result is higher than the findings of Tsehay et al. (2014) and Melese (2016), who reported a seroprevalence of 3.6\% in eastern and $3.7 \%$ in southern Ethiopia, respectively. Higher seroprevalence 
than the current study is reported by Yohanis (2012) 9.6\% and Muluken (2016) $7.5 \%$ in the Afar region. Seroprevalence of $5.2 \%$ in goats and $4.2 \%$ in sheep was estimated in the present study. This result is in agreement with the findings of Feyisa et al. (2007), Yohanis (2012) and Deddefo et al. (2015), who reported $5.8 \%$ in goats and $4.9 \%$ sheep, and $4.9 \%$ in goats and $4.4 \%$ in sheep, respectively. However, the current result is higher than the findings of Teshale et al. (2006), who reported a seroprevalence of $1.7 \%$ in goats and $1.6 \%$ in sheep. Similarly, Mengistu (2007) reported 3.2\% and 1.6\% seroprevalence of brucellosis in sheep and goats, respectively. This variation may be due to differences in environmental factors, breed of sheep and goats, management and production system.

A statistically significant difference was observed in the Brucella seropositivity of sheep and goat among different age groups $(\mathrm{p}<0.05)$. The odds of Brucella seropositivity in older sheep and goats were almost four times $(\mathrm{OR}=3.9)$ more likely than in the younger category. This could be explained by the fact that sexually mature animals are more susceptible to Brucella infection than sexually immature animals since sex hormones that encourage growth and multiplication of Brucella organism, probable increase in concentration with age and sexual maturity (Quinn et al., 2004; Radostits et al., 2007). Significantly higher seropositivity in older small ruminants than younger can be attributed to the practice of leaving younger around home premises when adult small ruminants were taken to a communal grazing area. This decreases the risk of younger's being exposed to infection from common grazing and watering points (Kiputa et al., 2008). This finding is in line with the reports of Megersa et al. (2011a), Yohanis, (2012) and Muluken (2016), who reported a significant association between age and Brucella seropositivity in sheep and goats.

Reproductive status of sheep and goat is significantly associated with Brucella seropositivity where pregnant sheep and goat were about three $(\mathrm{OR}=2.6$, $\mathrm{p}<0.05)$ times more likely than in non-pregnant ones. This could be explained by the fact that susceptibility to Brucella infection is increased after sexual maturity and especially with pregnancy. This is due to Brucella organisms prefer uterus in which allantoic fluid factors such as erythritol could stimulate the growth of Brucella and elevate in the placenta and fetal fluid from about the second trimester of pregnancy (Coetzer and Tustin, 2004; Radostits et al., 2007). This finding is in line with the report of Yohanis (2012), who stated that brucellosis was associated with the reproduction status of sheep and goats. Gestation period at abortion is significantly associated with Brucella seropositivity whereby seropositivity about two $(\mathrm{OR}=2.4, \mathrm{p}<0.05)$ times more likely in 
the third-trimester stage than those have no history of abortion. This can be explained by the presence of higher concentration erythritol produced naturally by the developing fetus favors the multiplication of Brucella organisms, where it causes degeneration and necrosis of the cotyledons leading to abortion from the last months of gestation (Smith et al., 2002; Coetzer and Tustin, 2004). Besides, in highly susceptible nonvaccinated pregnant sheep and goat, abortion occurs in the last month of pregnancy is a cardinal feature of Brucella infection (Radostits et al., 2007). This finding was supported by the reports of Muluken (2016), and Coetzer and Tustin (2004), who indicated a significant association between seropositivity of Brucella infection and gestation stage in sheep and goats.

Species mix is also associated with Brucella seropositivity where sheep and/ goats kept together with cattle is almost three $(\mathrm{OR}=2.8)$ times more likely to be positive for Brucella antibody than a single species flock. Cross-species infection with other Brucella species, especially B. abortus, has been documented in sheep and goat as a cause of Brucella infection (Glenn and Karen, 2005). Multiple livestock species herding together, especially keeping of goat and sheep along with cattle has been reported as an important determinant risk factor of Brucella seropositivity (Abbas and Agabu, 2002). Keeping sheep in contact with Brucella infected goat, also a potential risk factor for brucellosis spread among sheep flocks (Radostits et al., 2007). However, this finding is not supported by the reports of Coelho et al. (2013), who stated herding of small ruminants with cattle were not risk factors for brucellosis. This difference in Brucella seropositivity of species composition recorded in the different study areas may be associated with the differences in agroecology, management system and breed used in each study.

Flock size is associated with Brucella seropositivity in sheep and goat with large flock size was about three $(\mathrm{OR}=2.7)$ times more odd of brucellosis than small flock size. Flock size has previously been reported as an important determinant for transmission of Brucella organism between susceptible and infected animals (Omer et al., 2000) and because of one positive animal was at least available in large flock size compared with small flock size (Al-majali, 2005). This finding also related to a higher density of animals per flock. Keeping a large flock allows greater contact among animals. This makes a higher bacteria load in the environment and as a result, the probability of brucellosis transmission will be increased. Moreover, grazing in the communal pasture may facilitate the contact between infected and none infected flocks (Kaba- 
gambe et al., 2001; Coelho et al., 2013). The association of flock size with the seropositivity in the present finding is confirmed with previous results (Kabagambe et al., 2001; Al-majali, 2005; Coelho et al., 2007; Coelho et al., 2013; Tegegn et al., 2016;).

In the current study, no statistically significant difference ( $p>0.05)$ was detected in seroprevalence of Brucella antibody between aborted and none aborted sheep and goats. This suggests that brucellosis may not be associated with abortion in sheep and goat in study areas. This could be true as abortion in sheep and goat has multiple causes, infectious (Toxoplasma gondii, Leptospira spp, Listeria spp, Salmonellae spp, Coxiella burnetti) and non-infectious (heat stress, nutritional deficiencies, trauma, toxic substances, etc) other than brucellosis. It is known that only seropositivity does not certainly associate with abortion in all conditions. It is important to identify the actual causes in the aborting sheep and goats and/ or in the aborted fetus or placental tissues to confirm the pathogen is accountable for abortion (Morris et al., 2018). This result is in line with the reports of Gebremedhin (2015) and Wubishet et al. (2017), who reported that the risk of Brucella seropositivity was not associated with abortion. However, this result is inconsistent with some previous studies in Ethiopia (Tassew and Kassahun, 2014; Asmare et al., 2013) that stated brucellosis was associated with abortion in sheep and goats. This variation may be due to differences in agroecology, breed, management and husbandry condition in the area. This can also be differences between the study areas regarding conditions that could favor the transmission of various causes of abortion (Radostits et al., 2007).

\section{Conclusions}

In the present study, the high seroprevalence of brucellosis was recorded in sheep and goat. Older age, mixed flock, pregnancy, late term gestation, and larger flock size have been noted as the most important factors for recovering higher proportion of Brucella reactors in sheep and goats. The present study also indicated that the presence of higher brucellosis in sheep and goat with the history of abortion than those have no history of abortion. Hence, it is important to carry out further study to identify the circulating Brucella species using molecular tools and other potential causes of abortion in sheep and goats. Besides, this study warrants the need for further investigation on Brucella infection public health impact in the study area. 


\section{Acknowledgments}

The authors would like to thank the Jimma University College of Agriculture and Veterinary Medicine for financial support. Moreover, the authors also acknowledge the Ethiopian Institute of Agricultural Research for logistic support.

\section{Conflict of interests}

The authors have not declared any competing of interests

\section{References}

Abbas, B. and Agabu, H.A., 2002. A review of camel brucellosis. Prev. Vet. Med., 55:4756.

Addis, S.A. and Desalegn, A.Y., 2018. Comparative seroepidemiological study of brucellosis in sheep under smallholder farming and governmental breeding ranches of central and North East Ethiopia. J. Vet. Med., Volume 2018, Article ID 7239156, 12 pages https://doi.org/10.1155/2018/7239156.

Akhvledian, T., Clark, D.V., Chubabria, G., Zenaishvili, O. and Hepburn, M.J., 2010. The changing pattern of human brucellosis: clinical manifestations, epidemiology and treatment outcomes over three decades in Georgia. BMC. Infec. Dis., 10:346.

Al-Majali, A.M., 2005. Seroepidemiology of caprine brucellosis in Jordan. Small Rumin. Res., 58, 13-18.

Alton, G.G., 1990. Brucella melitensis. In: Animal Brucellosis. Nielsen K and Duncan R (eds). CRC Press, Boca Raton, Florida, USA, pp. 383-409.

Asmare, K., Asfaw, Y., Gelaye, E. and Ayelet, G., 2010. Brucellosis in extensive management system of Zebu cattle in Sidama Zone, Southern Ethiopia. Afr. J. Agric. Res., 5:257-263.

Asmare, K., Megersa, B., Denbarga, Y., Abebe, G., Taye, A., Bekele, T., Gelaye, E., Zewdu, E., Agonafir, A., Ayelet, G. and Skjerve, E., 2013. Study on seroprevalence of caprine brucellosis under three livestock production systems in southern and central Ethiopia. Trop. Anim. Hlth. Prod., 45:555-560.

Beruktayet, W. and Mersha, C., 2016. Review of Cattle Brucellosis in Ethiopia. Acad. J. Anim. Dis., 5(2):28-39.

Bokko, P.B., 2011. Pregnancy Wastage in Sheep and Goats in the Sahel Region of Nigeria, Nig. Vet. J., 32(2):120-126.

Coelho, A.M., Coelho, A.C. and Rodrigues, J., 2013. Seroprevalence of sheep and goat brucellosis in the northeast of Portugal. Archivos de Med. Vet., 45:167-172.

Ethiop. Vet. J., 2020, 24 (1), 15-33 
Coelho, A.M., Coelho, A.C., Roboredo, M. and Rodrigues, J., 2007. A case-control study of risk factors for brucellosis seropositivity in Portuguese small ruminant herds. Prev. Vet. Med., 82: 291-301.

Coetzer, J.W. and Tustin, R.C., 2004. Infectious diseases of livestock, $3^{\text {rd }}$ ed. South Africa Oxford University press, pp. 34-39.

CSA, 2017. Livestock and Livestock Characteristics, Agricultural sample Survey, Addis Ababa, Ethiopia. Statistical Bulletin, 2(583):9-13.

Dabassa, G., Tefera, M. and Addis, M., 2013. Small Ruminant Brucellosis: Serological Survey in Yabello District, Ethiopia. Asian J. of Animal Sci., 7:14-21. DOI: 10.3923/ajas.2013.14.21

Daniel, G.M. and Marley, M.S.D., 2008. Infectious causes of embryonic and fetal mortality. Theriogenology, 70(3):270-285. doi: 10.1016/j.theriogenology.2008.04.018.

Deddefo, A., Sisay, T. and Tuli, G., 2015. Seroprevalence and risk factors of small ruminant brucellosis in selected districts of Arsi and East Shoa Zones, Oromia region, Ethiopia. Afr. J. Microbiol. Res., 9(19):1338-1344. DOI: 10.5897/AJMR2015.7400

Dohoo, I., Martin, W. and Stryhn, H., (2009). Veterinary epidemiologic research, $2^{\text {nd }}$ ed. AVC, Charlottetown, Prince Edward Island, pp. 239-249.

ESGPIP (Ethiopia Sheep and Goat Productivity Improvement Program), 2011. Control and prevention of common reproductive diseases of Sheep and Goats. Technical bulletin, no. 48 .

ESGPIP (Ethiopia Sheep and Goat Productivity Improvement Program). Body condition scoring of sheep and goat, Techinical Bulletin No. 8 http://www.esgpip.org/ PDF/Technical\%20bulletin\%20No8.html.

ESGPIP (Ethiopia Sheep and Goat Productivity Improvement Program), 2009. Technical bulletin, No. 23, Estimation of weight and age of sheep and goats, pp. 8-9.

FAO, 2003. Guidelines for coordinated human and animal brucellosis surveillance. FAO In: Proceedings of Animal Production and Health Conference, Paper 156, Rome, Italy, pp. 1-45.

Feyisa. A.., Sori, T. ., Ejeta, G., Fikru, R. and Laikemariam, Y., 2007. Distribution of brucellosis among small ruminants in the pastoral region of Afar, Eastern Ethiopia. Rev. sci. tech. Off. int. Epiz., 26:731-739.

Gebremedhin, E.Z., 2015. Seroepidemiology of ovine brucellosis in East and West Shewa Zones of Oromia Regional State, Central Ethiopia. J. Vet. Sci. Technol., 6:265.

Gizaw, S., Hoekstra, D., Gebremedhin, B. and Tegegne, A., 2015. Classification of small ruminant production sub-systems in Ethiopia: Implications for designing develop- 
ment interventions. LIVES Working Paper 5. Nairobi, Kenya: International Livestock Research Institute (ILRI), pp.1-19.

Glenn, J.S. and Karen, W.P., 2005. Veterinary Microbiology: Bacterial and Fungal agents of animal diseases, pp. 200-203.

Kabagambe, E.K., Elzer, P.H., Geaghan, J.P., Opuda-Asibo, J., Scholl, D.T. and Miller, J.E., 2001. Risk factors for Brucella seropositivity in goat herds in Eastern and Western Uganda. Prev. Vet. Med., 52:91-108.

Kenyon, P.R., Maloney, S.K. and Blache, D., 2014. Review of sheep body condition score in relation to production characteristics, New Zealand J. Agri. Res., 57(1):38-64.

Kiputa, V.P.S., Kimera, S.I. and Wambura, P.N., 2008. Studies on the role of trade cattle in the transmission of brucellosis in Karagwe district, Tanzania. Tanzania Vet. J., 25(1):48-59.

Libeau, G., Préhaud, C., Lancelot, R., Colas, F., Guerre, L., Bishop, D. and Diallo, A., 1995. Development of a competitive ELISA for detecting antibodies to the peste des petits ruminant virus using a recombinant nucleoprotein. Res. Vet. Sci., 58: 50-55.

Livestock Marketing Authority (LMA), 2005. Brief base line information on Ethiopian Livestock resource base and its trade, Addis Ababa, Ethiopia.

Margatho, G., Vicente, R.E, Hélder, Q. and João, S., 2019. The Effects of Reproductive Disorders, Parity, and Litter Size on Milk Yield of Serrana Goats, Animals, 9:968.

McDermont, J.J. and Arimi, S.M., 2002. Brucellosis in sub-Saharan Africa: Epidemiology, Control and Impact. Vet. Microbiol., 20:111-134.

Megersa, B., Mohammed, H., Tefera, M. and Tolosa, T., 2011a. Small ruminant brucellosis and community perception in Jijiga district, Somali Regional State, Eastern Ethiopia, Trop. Anim. Hlth. Prod., 43:893-898.

Megersa, B., Biffa, D., Abunna, F., Regassa, A., Godfroid, J. and Skjerve, E., 2011b. Seroprevalence of brucellosis and its contribution to abortion in cattle, camel, and goat kept under pastoral management in Borana, Ethiopia. Trop. Anim. Hlth. Prod., 43:651-656. doi: 10.1007/s11250-010-9748-2.

Melese, Y., 2016. Isolation, phenotype characterization and Seroprevalence Survey on small ruminant brucellosis in Arba Minch Zuria and Mirab Abaya districts of Gamo Gofa, Southern Ethiopia. MSc. Thesis, Addis Ababa University. College of Veterinary Medicine, Bishoftu, Ethiopia.

Mengistu, M., 2007. Seroepidemiology of brucellosis in small ruminants in Southern Ethiopia. MSc. Thesis, Faculty of Veterinary Medicine, Addis Ababa University, Debre Zeit, Ethiopia. 
Mirkena, T., Duguma, D., Willam, A., Wurzinger, M. and Haile, A., 2011. Community-based alternative breeding plans for indigenous sheep breeds in four agroecological Zones of Ethiopia. J. Anim. Breed Genet, 10(1):1-10. doi: 10.1111/j.14390388.2011.00970.x.

Mohammed, M., Mindaye, S., Hailemariam, Z., Tamerat, N. and Muktar, Y., 2017. Sero-Prevalence of Small Ruminant Brucellosis in Three Selected Districts of Somali Region, Eastern Ethiopia. J. Vet. Sci. Anim. Hus., 5(1):105.

Morris, M.J., Sookhoo, J., Blake, L., Brown, J.A., John, J., Ali, S., Sarjusingh, G., St Aime, J., Amoroso, E.H. and Oura, C.A.L., 2018. Serosurvey for Infectious Agents Associated with Subfertility and Abortion in Dairy Cattle in Trinidad and Tobago, West Indies. Vet Sci., 5(2):51.

Muluken, T., 2016. Seroprevalence of Brucellosis and Isolation of Brucella from small ruminants that had history of recent abortion in selected Kebeles of Amibara District, Afar Region, Ethiopia. MSc. Thesis, Addis Ababa University, Bishoftu, Ethiopia.

Njeru, J., Wareth, G., Melzer, F., Henning, K., Pletz, M.W., Heller, R. and Neubauer, H., 2016. Systematic review of brucellosis in Kenya: disease frequency in humans and animals and risk factors for human infection. BMC Public Health, 16:853.

OIE, 2004. Manual of the diagnostic tests and vaccines for terrestrial animals, $5^{\text {th }} \mathrm{Ed}$. Office International des Epizooties, Paris, France, pp. 409-438.

OIE, 2009. Caprine and Ovine Brucellosis (Excluding Brucella ovis), In: OIE (ed). Manual of Diagnostic Tests and Vaccines for Terrestrial Animals, Vol. OIE-World Organization for Animal Health, Office International des Epizooties, pp. 2-8.

Omer, M.K., Skjerve, E., Woldehiwet, Z. and Holstad, G., 2000. Risk factors for Brucella spp. infection in dairy cattle farms in Asmara, State of Eritrea. Prev. Vet. Med., 46:257-265.

Pappas, G., Papadimitriou, P., Akritidis, N., Christou, L. and Tsianos, E.V., 2006. The new global map of human brucellosis. Lancet Infect. Dis., 6:91-9.

Quinn, P.J., Carter, M.E., Markey, B. and Carter, G.R., 2004. Clinical Veterinary Microbiology. Ireland, pp. 261-267.

Radostits, O.M., Gay, C.C., Hinclcliff, K.W. and Constable, P.O., 2007. Veterinary medicine: A text book of the disease of cattle, sheep, pigs, goat and horses, $10^{\text {th }} \mathrm{ed}$. London, Saunders, pp. 963-1110.

Shirima, G. and Kunda, J., 2016. Prevalence of brucellosis in the human, livestock and wildlife interface areas of Serengeti National Park, Tanzania. Onderstepoort J. Vet. Res., 83(1):4. 
Sintayehu, G., Melesse, B., Abayneh, D., Sintayehu, A., Melaku, S., Alehegne, W., Mesfin, S., De Blas, I., Casal, J., Allepuz, A., Martin-Valls, G., Africa, T. and Abera, K., 2015. Epidemiological survey of brucellosis in sheep and goats in selected pastoral and agro-pastoral lowlands of Ethiopia, Rev. sci. tech. Off. int. Epiz., 34(3):881-893.

Smith, H.A., Jones, T.C. and Hunt, R.D., 2002. Veterinary Pathology. $4^{\text {th }}$ (ed.) Lea and Ferbiger, Philadelphia, USA, pp. 594-598.

Tassew, H. and Kassahun, F., 2014. Sero-epidemiological study of camel brucellosis in Mehoni District, south eastern Tigray. J. Microbiol. Res., 4(1):18-23.

Tegegn, A.H., Feleke, A., Adugna, W. and Melaku, S.K., 2016. Small Ruminant Brucellosis and Public Health Awareness in Two Districts of Afar Region, Ethiopia. J. Vet. Sci. Technol., 7:335.

Teshale, S., Muhie, Y., Dagne, A. and Kidanemariam, A., 2006. Seroprevalence of small ruminant brucellosis in selected districts of Afar and Somali pastoral areas of Eastern Ethiopia: the impact of husbandry practice. Revue Med. Vet., 157(11): 557-563.

Thrusfield, M., 2005. Veterinary Epidemiology, $3^{\text {rd }}$ Edn., Blackwell Publishing, England, pp. 345-543.

Tsehay, H., Getachew, G., Morka, A., Tadesse, B., and Eyob, H., 2014. Seroprevalence of brucellosis in small ruminants in pastoral area of Oromia and Somali regional state of Ethiopia. J. Vet. Med. Anim. Health, 6(11):289-294.

Tulu, D., Deresa, B., Begna, F. and Gojam, A, 2018. Review of common causes of abortion in dairy cattle in Ethiopia. J. Vet. Med. Anim. Health, 10(1):1-13.

Villaquiran, M., Gipson, T.A., Merkel, R.C., Goetsch, A. L. and Sahlu, T., 2007. Body condition scores in goats in Meat Goat Production Handbook, Langston University.

Wesinew, A., Moti, Y., Hailu, D. and Tadele, T., 2013. Control and prevention of brucellosis in small ruminants: time for action. J. Vet. Res., 170:97-98.

Wubishet, Z.W., Sadik, K., Abdi, A., Abdallah, B., Huqa, L., Alemayehu, B., Mokonin, B., Getachew, A. and Getachew, K., 2017. Small ruminant brucellosis and awareness of pastoralist community about zoonotic importance of the disease in Yabello districts of Borena Zone Oromia regional state, southern Ethiopia. J. Zoonotic Dis., $4(2): 27-36$

Yohanis, G., 2012. Epidemiological investigation of brucellosis in ruminants and humans in Yabello districts of Borena pastoral area, Oromia, Ethiopia. MSc. Thesis, Addis Ababa University, Bishoftu, Ethiopia. 